\title{
Applications of a New Fluorimetric Enzyme Assay for the Diagnosis of Aspartylglucosaminuria
}

\author{
Ya. V. Voznyi ${ }^{2}$, J. L. M. Keulemans ${ }^{1}$, W. J. Kleijer ${ }^{1}$, P. Aula ${ }^{3}$, \\ G. R. GRAY ${ }^{2}$ and O. P. VAN DIGGELEN ${ }^{1 *}$ \\ ${ }^{1}$ Department of Clinical Genetics, Erasmus University, Rotterdam P.O. Box 1738, \\ 3000 DR Rotterdam, The Netherland: ${ }^{2}$ Department of Chemistry, University of \\ Minnesota, Minneapolis, USA; ${ }^{3}$ Department of Medical Genetics, University of \\ Turku, Turku, Finland
}

\begin{abstract}
Summary: L-Aspartic acid- $\beta$-7-amido-4-methylcoumarin is a sensitive and specific fluorogenic substrate for lysosomal glycoasparaginase (aspartylglucosaminidase). Fibroblasts and leukocytes from 8 patients with aspartylglucosaminuria, showed $1-7 \%$ of the mean normal glycoasparaginase activity. Heterozygotes showed intermediate activities. Glycoasparaginase activity in chorionic villi, cultured trophoblasts, cultured amniotic fluid cells and amniotic fluid was readily detectable, indicating that prenatal analysis of aspartylglucosaminuria should be possible with this assay. $\beta$-Aspartyl-4-methylumbelliferone was synthesized but this potential substrate can not be used to assay glycoasparaginase since it hydrolyses spontaneously.
\end{abstract}

Aspartylglucosaminuria (AGU; McKusick 208400) is a rare autosomal recessive hereditary disorder of glycoprotein catabolism characterized by severe mental retardation with facial and skeletal abnormalities (for review see Aula et al 1982; Beaudet and Thomas, 1989). The underlying defect is a deficiency of aspartylglucosaminidase (1-aspartamido- $\beta$ - $N$-acetylglucosamine aminohydrolase, EC 3.5.1.26; Pollitt et al 1968), which results in accumulation of 2-acetamido-1- $\beta$-(L-aspartamido)-1,2-dideoxy- $\beta$-D-glucose (aspartylglucosamine) in tissues and urine (Palo and Mattsson, 1970; Maury, 1979; Aula et al 1980).

Recent studies by Kaartinen et al (1992) showed that aspartylglucosaminidase in fact has a broad substrate specificity. It has activity towards L-asparagine- $N$ acetylglucosamine containing glycoasparagines of various sizes with or without the di- $N$-acetylchitobiose moiety, and even towards $\beta$-L-aspartylmethyl ester. Since the specificity of aspartylglucosaminidase is apparently determined by the asparagine moiety and not by $N$-acetylglucosamine, these authors proposed the more appropriate

*Correspondence

MS received 20.5.93 Accepted 12.7.93 
name glycoasparaginase for this enzyme, which emphasizes that aspartylglucosaminidase is in fact an asparaginase.

Since Makino et al (1966) described the glycoasparaginase assay with aspartylglucosamine this has been the assay of choice to diagnose AGU patients and has also been used for prenatal diagnosis (Aula et al 1982,1984). This assay is based on the colorimetric determination of free $N$-acetylglucosamine, which is relatively insensitive and susceptible to minor changes in the reagents used. In this paper we describe a simple, reproducible, fluorimetric assay for glycoasparaginase using Laspartic acid- $\beta$-7-amido-4-methylcoumarin (Asp-AMC). After completion of this work Mononen et al (1993) recently published a brief description of the sensitivity and specificity of an Asp-AMC-based glycoasparaginase assay. Here we describe details of our assay and show its usefulness for the pre- and postnatal diagnosis of aspartylglucosaminuria and detection of heterozygotes.

\section{MATERIALS AND METHODS}

Total leukocytes were isolated from heparinized blood as described previously (van Diggelen et al 1990) and frozen before use. Skin fibroblasts and amniotic fluid cells were cultured according to routine procedures in Ham's F10 medium supplemented with $10 \%$ fetal bovine serum and antibiotics. The cells were harvested with trypsin 7 days after the last subculture and stored at $-70^{\circ} \mathrm{C}$ until use. Fibroblasts from AGU patients were obtained from the European Human Cell Bank (Rotterdam, The Netherlands) and blood samples from AGU patients and their heterozygous parents were from Finnish patients.

For the standard glycoasparaginase assay homogenates were prepared by sonication of cell material in water. Reaction mixtures consisted of $10 \mu$ l homogenate (20 $\mu \mathrm{g}$ protein for fibroblasts; $30 \mu \mathrm{g}$ for leukocytes) or $10 \mu \mathrm{l}$ amniotic fluid and, $20 \mu \mathrm{l}$ $1.5 \mathrm{mmol} / \mathrm{L}$ L-aspartic acid- $\beta$-7-amido-4-methylcoumarin (Asp-AMC; Sigma St Louis, MO, USA) in McIlvain's phosphate-citrate buffer $\mathrm{pH}$ 6.5.

After incubation for $24 \mathrm{~h}$ at $37^{\circ} \mathrm{C}$ the reactions were terminated by the addition of $200 \mu 1$ McIlvain's phosphate-citrate buffer $\mathrm{pH} 4.5$, and the fluorescence of 7-amido4-methylcoumarine (AMC) was measured on a fluorimeter (Fluoroskan, Titertek) using the filter setting of methylumbelliferone (excitation $355 \mathrm{~nm}$, emission $460 \mathrm{~nm}$ ). Protein was determined as described previously (van Diggelen et al 1990).

\section{RESULTS}

Free 7-amido-4-methylcoumarin (AMC) has an excitation maximum at $345 \mathrm{~nm}$ and emission maximum at $440 \mathrm{~nm}$. The intensity of emission is virtually constant between $\mathrm{pH} 4$ and $\mathrm{pH}$ 10.7. Asp-AMC appears to be somewhat unstable at $\mathrm{pH} \mathrm{10.7,}$ which is a commonly used $\mathrm{pH}$ for stopping enzyme assays with 4-methylumbelliferyl substrates. We have investigated whether the excitation and emission wavelengths used for 4-methylumbelliferone (excitation $355 \mathrm{~nm}$, emission $460 \mathrm{~nm}$ ) gave acceptable results for AMC. At $460 \mathrm{~nm}$, fluorescence of $\mathrm{AMC}$ is only reduced to $2 / 3$, whereas blank readings of Asp-AMC are reduced to $1 / 3$. In contrast to 4-methylumbelliferyl substrates, AMC conjugates show considerable fluorescence and the reduction of 
blank readings is advantageous. These results made us decide to use the excitation and emission settings of 4-methylumbelliferone for all experiments described below.

The properties of glycoasparaginase from leukocytes and fibroblasts were investigated. The $\mathrm{pH}$ optimum was between $\mathrm{pH} 6$ and $\mathrm{pH} 6.5$ (Figure 1), which is high for a lysosomal enzyme; moreover the activity does not fall appreciably up to $\mathrm{pH} 8.5$. The apparent $K_{\mathrm{m}}$ was estimated to be $0.15 \mathrm{mmol} / \mathrm{L}$ (Figure 2). The glycoasparaginase activity increased nearly linearly with time up to $24 \mathrm{~h}$ of incubation; using this incubation time, a linear relationship between the amount of protein and glycoasparaginase activity was found up to $50 \mu \mathrm{g}$ protein (data not shown). From these experiments, standard assay conditions were chosen as described in Materials and Methods. Addition of Triton X-100 to standard reaction mixtures $(0.25 \% \mathrm{w} / \mathrm{v})$ had no effect on the glycoasparaginase activities in control leukocytes and fibroblasts (data not shown).

Assayed under standard conditions, all 8 investigated AGU patients ( 5 of Finnish descent, 2 from the Netherlands and 1 from Turkey), had a profound deficiency of glycoasparaginase in fibroblasts, leukocytes and plasma (Table 1). Carriers showed about half normal activity. Plasma appears to be a poor enzyme source for carrier detection.

The glycoasparaginase activity in chorionic villi, cultured chorionic villus cells, amniotic fluid cells and amniotic fluid was determined under standard conditions. The activities in these cells were comparable to those in leukocytes and fibroblasts (Table 2). Unfortunately, no material from AGU affected fetuses was available.

A more convenient fluorogenic substrate for glycoasparaginase would be a 4methylumbelliferone-based substrate since these substrates do not fluoresce. We have

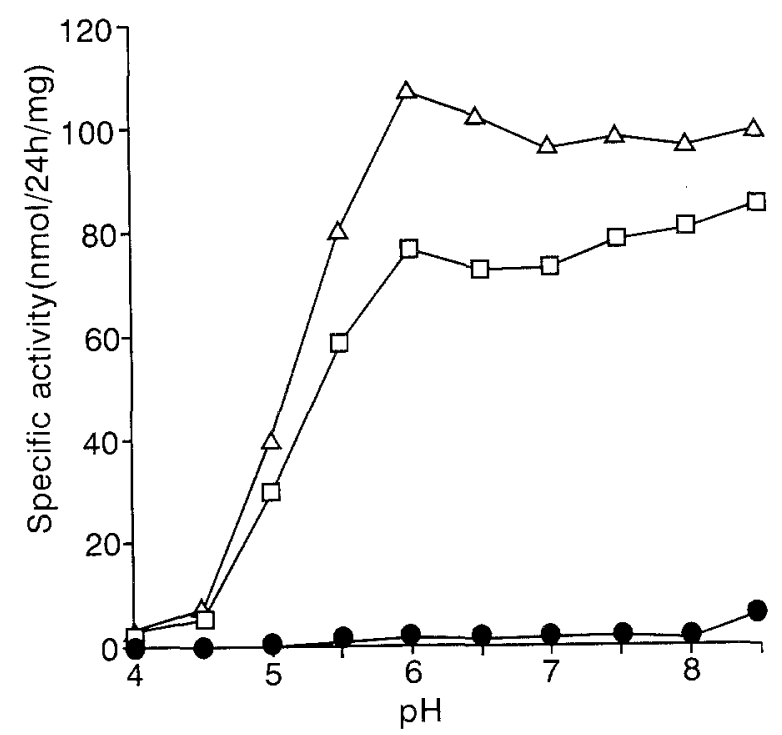

Figure 1 pH dependence of glycoasparaginase activity: normal leukocytes $(\square)$ and fibroblasts $(\triangle)$; AGU fibroblasts (O). Reaction conditions as in standard assay, except for $\mathrm{pH}$ 


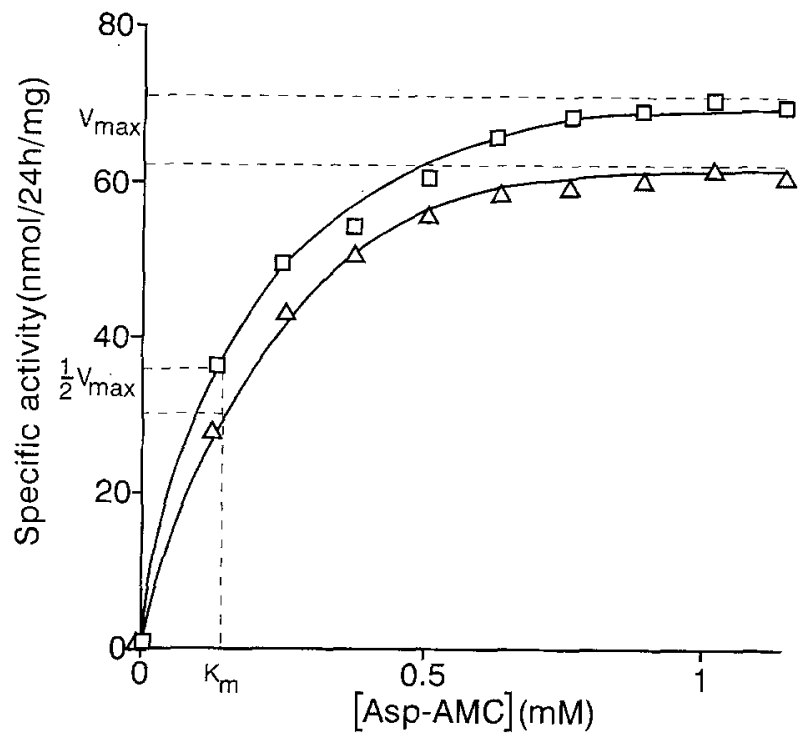

Figure 2 Michaelis-Menten plot of glycoasparaginase activity: normal leukocytes $(\square)$ and fibroblasts $(\triangle)$. Reaction conditions as in standard assay, except for Asp-AMC concentration

Table 1 Glycoasparaginase activity in fibroblasts, leukocytes and plasma from aspartylglucosaminuria patients and carriers

\begin{tabular}{|c|c|c|}
\hline & Range & $(M e a n \pm S D)$ \\
\hline $\begin{array}{l}\text { Fibroblasts } \\
\text { AGU patients }(n=5) \\
\text { AGU carriers }(n=2) \\
\text { Normal }(n=18)\end{array}$ & \multicolumn{2}{|c|}{$\begin{array}{l}\text { Glycoasparaginase (nmol/24 h per mg protein) } \\
0.8-2.5 \\
36 ; 27 \\
63-176\end{array}$} \\
\hline $\begin{array}{l}\text { Leukocytes } \\
\text { AGU patients }(n=4) \\
\text { AGU carriers }(n=10) \\
\text { Normal }(n=32)\end{array}$ & $\begin{array}{l}1.7-4.7 \\
12-41 \\
39-92\end{array}$ & $\begin{array}{l}(24 \pm 9) \\
(65 \pm 13)\end{array}$ \\
\hline $\begin{array}{l}\text { Plasma } \\
\text { AGU patients }(n=4) \\
\text { AGU carriers }(n=10) \\
\text { Normal }(n=6)\end{array}$ & $\begin{array}{l}\quad \text { Glyc } \\
1.4-3.8 \\
48-98 \\
68-149\end{array}$ & $\begin{array}{l}\text { h per ml) } \\
\qquad \begin{array}{l}(66 \pm 17) \\
(95 \pm 26)\end{array}\end{array}$ \\
\hline
\end{tabular}

synthesized $\beta$-aspartyl-4-methylumbelliferone as a potential substrate. Unfortunately, this compound hydrolyses spontaneously at $\mathrm{pH} 6.5$ at a rate of about $2 \%$ per minute at room temperature. The Asp-AMC analogue $\beta$-aspartyl-7-amido-4-trifluoromethylcoumarin was also synthesized. This compound was a substrate for glycoasparaginase but the activity was only $20 \%$ of the activity with Asp-AMC and had no advantages over Asp-AMC (data not shown). 
Table 2 Glycoasparaginase activity in normal chorionic villi, cultured trophoblasts, amniocytes and amniotic fluid

\begin{tabular}{llc}
\hline & \multicolumn{2}{l}{ Glycoasparaginase (nmol/24h per mg protein) } \\
\cline { 2 - 3 } & Range & $($ Mean $\pm S D)$ \\
\hline Chorionic villi $(n=11)$ & $28-59$ & $(38 \pm 9)$ \\
Cultured trophoblasts $(n=11)$ & $50-121$ & $(83 \pm 22)$ \\
Amniocytes $(n=12)$ & $38-120$ & $(68 \pm 21)$ \\
Amniotic fluid $(n=19)$ & $17-95$ & $(32 \pm 13)$ \\
(nmol/24h per ml; $16-18$ weeks gestation) & & \\
\hline
\end{tabular}

\section{DISCUSSION}

We have defined conditions for a fluorimetric assay of glycoasparaginase that is convenient for the diagnostic laboratory involved in enzyme analysis. These results extend the independent observation of Mononen et al (1992) who recently showed that L-aspartic acid- $\beta$-7-amido-4-methylcoumarin (Asp-AMC) is a specific and sensitive substrate. These authors briefly described an assay using a centrifugal analyser. Their glycoasparaginase activities in leukocytes and fibroblasts are of the same order of magnitude as ours; these authors found a ratio of activity in control leukocytes over that of control fibroblasts of 2.7. By contrast, this ratio with our assay was only 0.6 . Most clinical laboratories involved in the diagnosis of lysosomal storage disorders do not have a centrifugal analyser and commonly use 4-methylumbelliferyl substrates. We have therefore developed an assay with end-point measurement and showed that the excitation and emission wavelengths of 4-methylumbelliferone ( 355 and $460 \mathrm{~nm}$ ) can be used adequately for the determination of AMC.

Our Asp-AMC-based assay is more sensitive and has better reproducibility than the conventional glycoasparaginase assay based on the colorimetric determination of free $N$-acetylglucosamine (Makino et al 1966). The residual glycoasparaginase activities in fibroblasts, leukocytes and plasma of the 8 investigated patients were $1-7 \%$ of the mean control activity. Heterozygotes $(n=12)$ had reduced activities, suggesting the feasibility of carrier detection. With our assay the patient range was clearly separated from the preliminary heterozygote range. Using the colorimetric assay, Aula et al (1974) showed a small overlap between their patient and heterozygote ranges based on larger numbers. Our results suggest that our assay may show better separation between patient and carrier values.

In material obtained from control pregnancies the glycoasparaginase activities were readily detectable, suggesting the feasibility of prenatal detection of AGU with our fluorimetric assay in the first and second trimesters of pregnancy.

\section{ACKNOWLEDGEMENTS}

We thank Professor Hans Galjaard for his continuous support. We also thank Dr F.C.H.A. Kothe and the staff of the 'Bloedbank, Rotterdam' for providing indispensable blood samples from control individuals. 


\section{REFERENCES}

Aula P, Autio S, Raivio KO, Näntö V (1974) Detection of heterozygotes for aspartylglucosaminuria in cultured fibroblasts. Humangenetik 25: 307-314.

Aula P, Raivio KO, Maury P (1980) Variation of urinary excretion of aspartylglucosamine and associated clinical findings in aspartylglucosaminuria. $J$ Inher Metab Dis 3: 159-162.

Aula P, Autio S, Raivio KO, Rapola J (1982) Aspartylglucosaminuria. In Durand P, O'Brien JS, eds. Genetic Errors of Glycoprotein Metabolism Milano: Edi. Ermes 123-152.

Aula P, Rapola J, von Koskull H, Ämmälä P (1984) Prenatal diagnosis and fetal pathology of aspartylglucosaminuria. Am J Med Genet 19: 359-367.

Beaudet AL, Thomas GH (1989) Disorders of glycoprotein degradation In Scriver CR, Beaudet AL, Sly MD, Valle D, eds. The Metabolic Basis of Inherited Disease, 6th edn. New York: McGraw-Hill, 1614-1616.

Maury P (1979) Quantitative determination of 4- $N$-2-acetamido-2-deoxy- $\beta$-D-glucopyranosylL-asparagine in the urine of patients with aspartylglucosaminuria by gas-liquid chromatography. J Lab Clin Med 93: 718-723.

Kaartinen V, Mononen T, Laatikainen R, Mononen I (1992) Substrate specificity and reaction mechanism of human glycoasparaginase. $J$ Biol Chem 267: 6855-6858.

Makino M, Kojima T, Yamashina I (1966) Enzymatic cleavage of glycopeptides. Biochem Biophys Res Commun 24: 961-966.

Mononen IT, Kaartinen VM, Williams JC (1993) A flurometric assay for glycosylasparaginase activity and detection of aspartylglucosaminuria. Anal Biochem 208: 372-374.

Palo J, Mattsson K (1970) Eleven new cases of aspartylglucosaminuria. J Ment Defic Res 14: $168-173$.

Pollitt RJ, Jenner FA, Merskey H (1968) Aspartylglycosaminuria: an inborn error of metabolism associated with mental defect. Lancet 2: 253-255.

Van Diggelen OP, Zhao H, Kleijer WJ et al (1990) A fluorimetric enzyme assay for the diagnosis of Morquio disease type A (MPS IV A). Clin Chim Acta 187: 131-140. 